\title{
Program Pengembangan Minat Kewirausahaan Mahasiswa
}

\author{
Endah Andayani, Lilik Sri Hariani, Nurul Ain \\ Program Pascasarjana, Universitas Kanjuruhan Malang \\ endahandayani@unikama.ac.id, liliksrihariani@unikama.ac.id,nurulain@unikama.ac.id ${ }^{3}$
}

\begin{abstract}
The objective of developing entrepreneurship program to produce new entrepre-neurs. The methods in this activity were training, workshops, and observations. The results of implementation program among others, a very good commitment of tenants have been carried out all activities, the amount of attendance of tenants for each activity were $100 \%$, their activeness in each activity were good and the average activity in $78 \%$, the successful of program is good and the program success rate in $75 \%$. We hope all of the activities implementation of developing entrepreneurship program increase the tenants interesting in entrepreneurship. It is recommended for the team to assist tenant activities until they can be independent entrepreneurs.
\end{abstract}

Keywords: PKK; training; workshops; observation

\begin{abstract}
Abstrak
Tujuan Program Pengembangan Minat Kewirausahaan Mahasiswa adalah untuk menghasilan wirausahawan baru. Metode yang digunakan dalam kegiatan Program Pengembangan Minat Kewirausahaan Mahasiswa ini adalah pelatihan, workshop, dan observasi. Hasil dari pelaksanaan kegiatan adalah para tenant memiliki komitmen yang sangat baik untuk melaksanakan semua aktivitas, tingkat kehadiran dalam setiap kegiatan yang dilakukan sebesar 100\%, keaktifan mereka dalam setiap kegiatan juga baik dengan rata-rata keaktifan pada setiap kegiatan sebesar $78 \%$, keberhasilan program juga baik dengan rata-rata tingkat keberhasilan program sebesar 75\%. Dari rangkaian kegiatan yang telah dilakukan mampu menumbuhkan minat berwirausaha bagi para tenant. Disarankan bagi tim untuk terus mendampingi kegiatan tenant sehingga mereka dapat menjadi wirausahawan yang mandiri.
\end{abstract}

Kata kunci: PKK; pelatihan; workshop; observasi

\section{A. PENDAHULUAN}

Minat dalam diri seseorang tidak muncul dengan sendirinya, namun membutuhkan suatu proses. Hal ini sesuai dengan pendapat Slameto (2013) yang menyatakan bahwa minat tidak dibawa sejak lahir, melainkan diperoleh 
kemudian. Sementara Bahri (2008) mendefinisikan minat sebagai kecenderungan yang menetap untuk memperhatikan dan mengenang beberapa aktivitas. Seseorang yang berminat terhadap suatu obyek atau aktivitas akan memperhatikan secara konsisten dengan perasaan senang. Demikian juga bagi seorang yang berminat untuk menjadi wirausaha. Seseorang wirausaha harus memiliki tindakan berfikir kreatif yang membangun nilai dari sesuatu yang tidak tampak sebelumnya, berani mengambil risiko dan berperilaku inovatif yang dijadikan dasar, sumber daya, tenaga penggerak, tujuan, siasat, kiat dan proses dalam menghadapi tantangan hidup. Sehingga minat berwirausaha dapat diartikan sebagai suatu ketertarikan dalam diri seseorang untuk menciptakan suatu usaha dengan kreativitas dan inovasi tanpa ada paksaan dari orang lain. Minat berwirausaha perlu ditumbuh kembangkan di kalangan masyarakat termasuk mahasiswa karena berwirausaha memiliki manfaat yang banyak antara lain menambah daya tampung tenaga kerja. Dengan bertambanya daya tampung tenaga kerja diharapkan dapat mengurangi pengangguran dan meningkatkan pendapatan masyarakat.

Salah satu cara menumbuhkembangkan minat berwirausaha di kalangan mahasiswa dapat dilakukan dengan pemberlakuan kurikulum yang mencantumkan matakuliah kewirausahaan bagi seluruh program studi. Kurikulum adalah seperangkat rencana dan pengaturan mengenai tujuan, isi, dan bahan pelajaran serta cara yang digunakan sebagai pedoman penyelenggaraan kegiatan pembelajaran untuk mencapai tujuan pendidikan tertentu. Dengan dimasukkannya matakuliah kewirau-sahaan pada setiap program studi, maka secara kurikuler para mahasiswa dapat belajar tentang berbagai teori dan pengetahuan serta ketram-pilan kewirausahaan yang dapat dijadikan bekal dalam menekuni dan terjun ke dunia kewirausahaan baik selama menjadi mahasiswa maupun setelah mereka lulus.

Matakuliah kewirausahaan merupakan salah satu matakuliah wajib yang harus ditempuh mahasiswa Universitas Kanjuruhan Malang. Luaran yang diharapkan dari perkuliahan tersebut adalah mahasiswa menguasai prinsip-prinsip kewirausahaan, teori dasar kewirau-sahaan, dan menyusun business plan.

$\begin{array}{cccc}\text { Mahasiswa } & \text { Universitas } & \text { Kan- } \\ \text { juruhan } & \text { Malang } & \text { banyak } & \text { yang }\end{array}$
memperoleh hibah dari Kemenristekdikti baik Program Kreativitas Mahasiswa (PKM), Program Mahasiswa Wirausaha (PMW), maupun Program Hibah Bina Desa (PHBD). Dalam menjalankan kegiatannya mereka bukan hanya menjalankan bisnisnya sendiri, namun mereka juga bekerja sama dengan Unit Kegiatan Mahasiswa (UKM) untuk meningkatkan produktifitas mereka. Komoditas yang dijual atau yang dihasilkan oleh mahasiwa PKM dan PMW antara lain, kasur multi fungsi (portable), kaos cinta tanah air, mainan edukasi, mainan puzzle berbasis pendidikan karakter dan alat ukur tubuh ideal, susu kolostrum, tas meja portable untuk komputer, souvenir, sajadah pandai mengaji, busana muslim, pendeteksi borax bidang kuliner, dan beberapa inovasi lainnya di bidang teknologi dan peternakan. Namun setelah mendapatkan dana hibah kegiatan mereka terhenti setelah pelaporan. Kondisi ini tentu diperlukan suatu wadah dan proses yang mapan dalam membangun kapasitas entrepreneurship maha-siswa secara sistematik serta mengembangkan bisnis mahasiswa. Wadah tersebut dapat 
dilakukan melalui program pengembangan minat kewirausahaan mahasiswa.

Program pengembangan minat kewirausahaan mahasiswa Universitas Kanjuruhan Malang merupakan suatu sistem yang dapat memberikan peran lebih dari sekedar pelatihan kewirausahaan bagi tenant, tetapi mampu memotivasi, membina, dan mengembangkan wirausaha secara berkesinambungan berbasis informasi dan teknologi untuk membangun komunitas, sehingga mahasiswa bisa menjadi wirausaha yang tangguh dan dapat menjadi wirausahawan baru, mengembangkan business plan guna menangkap peluang-peluang bisnis di sekitar kampus dan di luar kampus dalam area Kabupaten/Kota, Provinsi, Nasional maupun, Internasional.

Metode yang dikembangkan dalam program ini meliputi pendidikan dan pelatihan kewirausahaan, observasi, penyusunan rencana bisnis, magang, dukungan permodalan, dan pendampingan usaha, dan diharapkan dapat: 1) Menciptakan wirausaha baru yang mandiri. 2) Meningkatkan keteram-pilan manajemen usaha bagi masyarakat industri, 3) Menciptakan metode pelatihan kewirausahaan yang cocok bagi mahasiswa. 4) Unit usaha yang dapat menghasilkan profit sebagai sumber generate revenue bagi Universitas Kanjuruhan Malang, dan 5) Pembuka atau penyedia lapangan kerja.

\section{B. PELAKSANAAN DAN METODE}

Peserta kegiatan sejumlah 20 tenant yang terdiri dari mahasiswa Universitas Kanjuruhan Malang dan alumni. Tenant adalah mahasiswa penerima hibah Dikti yang didanai pada tahun 2013-2017, mahasiswa yang memiliki bisnis, dan alumni yang memulai bisnis. Langkah-langkah rekruitmen, meliputi; 1) Sosialisasi program yang dilaksanakan tanggal 13 Juli 2018, sosialisasi ini dilakukan melalui pengumuman di mading kampus Universitas Kanjuruhan Malang, website kampus, dan sosial media (grup mahasiswa dan grup alumni), 2) Calon peserta mendaftarkan diri pada tanggal 14 dan 15 Juli 2018, sebelum dia masuk menjadi tenant; 3) Calon peserta mengikuti tes tulis untuk melihat potensi keilmuan yang dimiliki tentang dunia wirausaha, dilanjutkan dengan wawancara untuk mengetahui motivasi dan keseriusan peserta dalam program ini, pelaksanaan tes tulis dan wawancara dilaksanakan bersamaan pada saat calon tenant mendaftar; 4) Hasil seleksi ditentukan 20 orang nilai terbaik sebagai calon tenan, hasil seleksi diumumkan pada tanggal 15 Juli 2018; dan 5) Peserta harus mengisi lembar kesediaan untuk mengikuti program sampai tuntas.

Pelaksanaan kegiatan program pengembangan kewirausaan mahasiswa dilakukan secara partisipatif dengan metode transfer ilmu dari tim pengusul dan praktisi pelaku usha kepada tenant. Metode partisipatif dipilih karena memiliki kelebihan diantaranya keterlibatan aktif para tenent (sebagai subjek) sedangkan tim pengusul hanya sebagai fasilitator.

Kerangka pemecahan masalah dalam kegiatan dilakukan melalui pelatihan worskshop, dan observasi. Sebelum pelaksanaan kegiatan dilakukan pemetaan potensi yang dimiliki dan keinginan dari tenant, sehingga pelatihan, workshop, dan observasi yang dilaksanakan lebih efektif. Secara lebih rinci pelaksanaan kegiatan pemecahan permasalahan sebagai berikut:

1. Pembekalan kagiatan Program Pengembangan Minat Kewirausaan Mahasiswa 
Pembekalan dilakukan oleh semua tim pelaksana program pada tanggal 18 Juli 2018 di Ruang J5 Universitas Kanjuruhan Malang. Ketua tim pelaksana kegiatan memberikan penjelasan tentang tujuan dan manfaat dari kegiatan, hak dan kewajiban dari tenant.

2. Pelatihan dan workshop Vidiografi dalam Periklanan bagi Bisnis Start-up Pelatihan dan workshop Vidiografi dilaksanakan pada tanggal 19 Juli 2018 di Ruang A1 Universitas Kanjuruhan Malang. Pelatihan dan workshop dilakukan dengan memberikan penjelasan dan diskusi tentang materi kegiatan, kegunaan, dan manfaat kegiatan serta menambah wawasan dan pengetahuan para tenant tentang vidiografi dalam periklanan bagi bisnis start-up. Tenant mengikuti kegiatan pelatihan, setelah itu dilanjutkan workshop tentang pembuatan vidiografi dalam periklanan bagi bisnis start-up .

3. Pelatihan dan workshop On Line Shop

Pelatihan dan workshop On Line Shop pada tanggal 19 Juli 2018 di Ruang A1 Universitas Kanjuruhan Malang. Pelatihan dan workshop dilakukan dengan memberikan penjelasan dan diskusi tentang materi kegiatan, kegunaan, dan manfaat kegiatan serta menambah wawasan dan pengetahuan para tenant tentang On Line Shop. Tenant mengikuti kegiatan pelatihan, setelah itu dilanjutkan workshop tentang pembuatan situs On Line Shop

4. Observasi ke Usaha Mikro Kecil dan Menengah (UMKM)

Observasi ke UMKM dilksanakan pada tanggal 22 Juli 2018 di Kota Blitar, yaitu ke "Kampung Coklat", Industri Olahan Aneka Kripik "Anisa Jaya", dan Kerajianan "Batok Koi”.
Tujuan obsevasi ini adalah untuk melihat secara langsung kegiatan yang dilakukan oleh para pengusaha mulai dari proses produksi, pengemasan, sampai pemasaran yang dilakukan.

\section{HASIL DAN PEMBAHASAN}

Hasil kegiatan pembekalan, pelatihan dan workshop tentang Vidiografi dalam Periklanan bagi Bisnis Start-up dan On Line Shop, serta kegiatan observasi bagi para tenant di Universitas Kanjuruhan Malang dipaparkan dalam Gambar 1

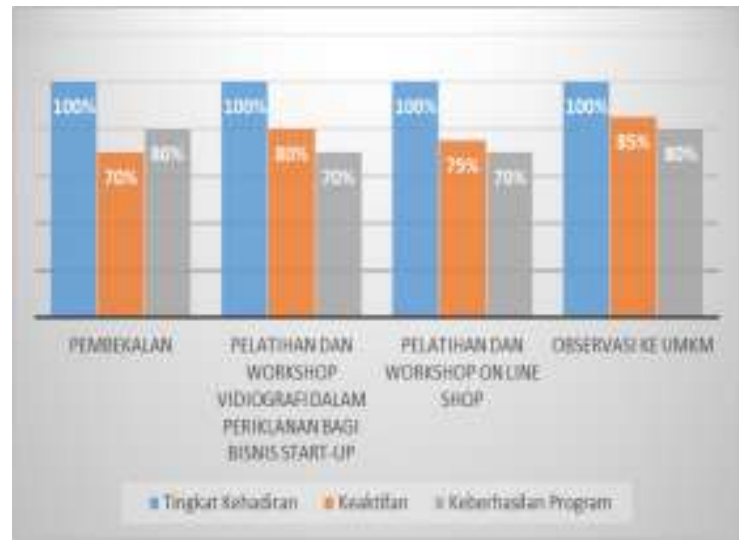

Gambar 1. Hasil kegiatan pelatihan, workshop, dan observasi

Berdasarkan Gambar 1 dapat diketahui bahwa para tenant memiliki komitmen sangat yang baik dalam kegiatan PPK, hal ini terbukti rata-rata tingkat kehadiran setiap kegiatan yang dilakukan sebesar 100\%. Keaktifan mereka dalam setiap kegiatan juga baik, rata-rata keaktifan pada setiap kegiatan sebesar $78 \%$. Keberhasilan program juga baik, rata-rata keberhasilan program sebesar $75 \%$.

Pembelakan dilaksanakan oleh semua tim pelaksana PPK. Setelah dilakukan pembekalan sebesar $80 \%$ tenant dapat memahami bahwa PPK merupakan suatu program yang 
dilaksanakan secara terintegrasi oleh perguruan tinggi untuk menhasilkan wirausaha-wirausaha baru baik bagi mahasiswa yang masih aktif maupun bagi para alumni. Untuk menumbuhkan minat berwirausaha, program PPK dilaksanakan dalam bentuk pelatihan, workshop kewirausahaan, dan obsevasi pada perusahaan yang mapan, Sehingga tujuan akhir program yaitu menciptakan wirausahawan baru yang mandiri bagi tenant yang sedang merintis usaha dapat berhasil.

Pelatihan dan workshop Videografi dalam Periklanan bagi Bisnis Start-up dilaksanakan oleh pemateri dari Jawa Timur Information Tecnology Creative (JITC) inkubator kewirausahaan Malang. JITC ini merupakan suatu komunitas dan organisasi inkubasi untuk mewadahi kreativitas berwirausaha. Dalam pelatihan tersebut sebesar $70 \%$ tenant dapat memahami tentang bagaimana cara membuat videografi dalam periklanan. Tenant sangat aktif dalam kegiatan tersebut, mareka banyak bertanya kepada pemateri dan langsung dipraktikan dalam kegiatan workshop.

Pelatihan dan workshop online shop disampaikan oleh Umi Tursini Ph.D., disamping seorang dosen beliau juga praktisi bisnis on line. Setelah pelatihan tentang bisnis on line, sebesar 75\% dari jumlah tenant dapat mahami bahwa dalam bisnis on line harus dapat meyakinkan kepada konsumen tentang kualitas barang yang dijualnya. Selain itu harga yang ditawarkan juga harus wajar. Hal ini dikarenakan bahwa pembeli zaman sekarang adalah pembeli yang cerdas, sebelum memutuskan untuk membeli mereka mencari tahu terlebih dahulu tentang produk yang akan dibelinya. Tenant juga dapat memahami bahwa untuk memulai bisnis on line; 1) berfokus pada satu kategori produk apa yang akan dijual dan siapa pangsa pasarnya; 2) memilih supplier dengan cermat, agar sebagai tenaga pemasaran dapat dipercaya oleh pelanggan; 3) memberikan informasi kontak yang jelas, dengan kontak yang jelas akan memudahkan komunikasi dengan pelanggan; 4) memulai melakukan promosi, pengenalan merek produk/jasa yang akan dipasarkan sangat penting untuk membuat calon pelanggan penasaran dan akhirnya mencari tahu dan tertarik untuk membeli produk/jasa yang ditawarkan, dan 5) melakukan inovasi dan kreativitas, meningkatkan inovasi dan kreativitas dalam bisnis on line sangat penting agar mampu bersaing dengan kompetitor yang lain.

Pelaksanaan observasi dilakukan di 3 (tiga) UMKM di kota Blitar, yaitu di Batok Koi yang memproduksi berbagai kerajinan dari bahan dasar batok, Kampung Coklat yang memproduksi olahan makanan dari coklat, dan Haya yang memproduksi olahan keripik dari bahan dasar pisang, nangka, pepaya, dan tape pohong. Setelah melakukan observasi ke UMKM sebesar $70 \%$ tenan menyatakan bahwa mereka memahami bagaimana memproduksi terutama olahan berbagai macam keripik yang rasanya sangat enak.

Dari kegiatan pelatihan, workshop, dan observasi yang telah dilaksanaka secara fisik para tenant memang belum dapat membuat Videografi dan On Line Shop, dan memproduksi berbagai macam olahan baik kerajinan maupun makanan. Pada saat artikel ini ditulis, kegiatan tenant masih terus berproses, tenant masih membuat bisnis plan dan melaksanakan magang di JITC dan bisnis on line milik Ibu Umi Tursini, Ph.D. Namun dari 4 (empat) kegiatan yang telah dilaksanakan, motivasi dan minat tenant untuk berwirausaha sudah baik. Minat 
tenant dalam berwirausaha terpapar pada Gambar 2.

Berdasarkan Gambar 2 diketahui bahwa setelah mengikuti kegiatan pelatihan, workshop, dan observasi sebesar $43 \%$ tenant memiliki minat yang sangat tinggi dan $21 \%$ memiliki minat yang tinggi untuk membuka usaha. Bagi tenant yang sudah memiliki minat yang sangat tinggi dan tinggi ini, tim harus tetap mendampingi dan terus memotivasi agar tenant benar-benar dapat mewujudkan keinginan mereka dalam membuaka usaha sesuai dengan pemampuan yang mereka miliki.

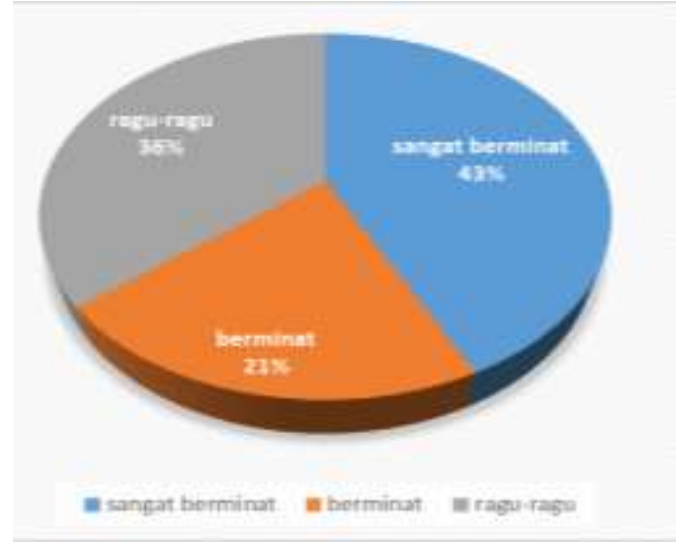

Gambar 2. Diagram minat tenant dalam berwirausaha

Sebesar $36 \%$ tenant masih raguragu untuk memulai usaha, mereka mengikuti kegiatan dalam program ini karena tertarik untuk menjadi wirausaha, tetapi masih ragu-ragu untuk memulai usaha. Bagi tenant yang masih ragu-ragu dalam memulai usaha ini, tim harus selalu melakukan pendampingan dan memotivasi agar tenant memiliki keberanian untuk mencoba melakukan usaha.

Faktor pendukung merupakan hal-hal positif yang memengaruhi keberhasilan program. Faktor pendukung dalam program ini antara lain: 1) Peserta memiliki komitmen yang tinggi dan tekat yang bulat untuk berwirausaha.
2) Peserta memiliki rasa tanggung jawab, terbukti dari tingkat kehadiran mereka dalam pelaksanaan pelatihan. 3) Peserta memiliki rasa percaya diri untuk berwirausaha. 4) Materi pelatihan relevan dengan potensi dan minat tenant. 5) Materi pelatihan merupakan materi yang dibutuhkan pada era revolusi industri 4.0 yang sedang booming saat ini.

Faktor penghambat merupakan hal-hal yang mengganggu kelangsungan dan kelancaran pelaksanaan program kegiatan diantaranya: 1) Ada peserta yang belum memiliki pengalaman dalam berwirausaha. 2) Kegiatan pelatihan yang dilaksanakan bertepatan dengan kegiatan kemahasiswaan yang lain. 3) Bagi alumni yang sudah bekerja (mengajar) waktunya kerja bertepatan dengan kegiatan pelatihan dan workshop

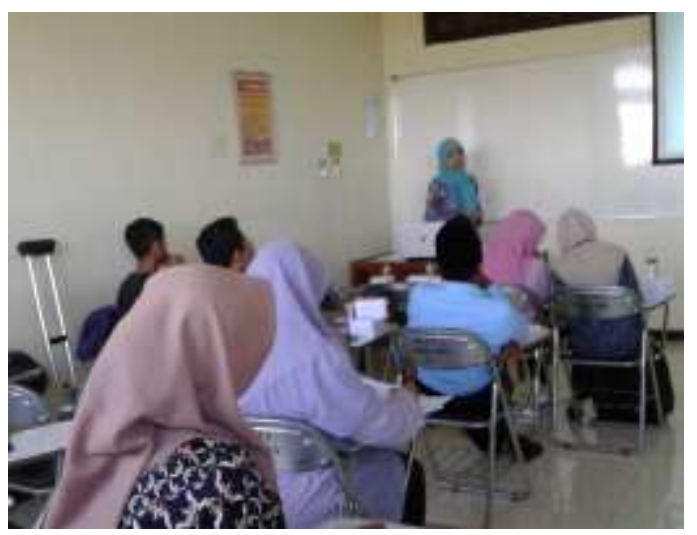

Gambar 3. Kegiatan pembekalan

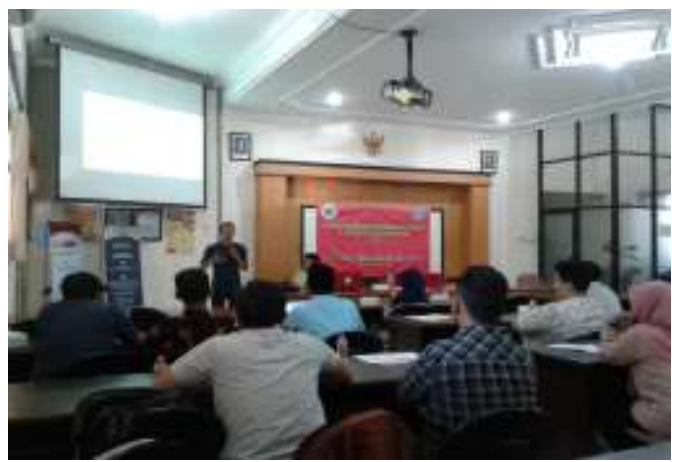

Gambar 4. Kegiatan pelatihan dan wokshop 


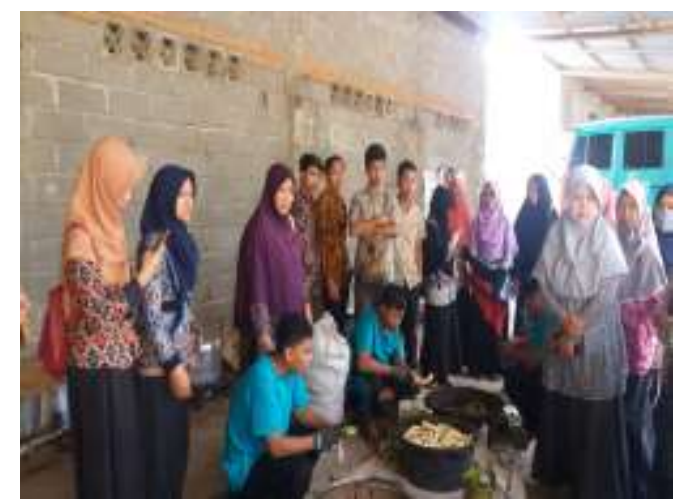

Gambar 5. Kegiatan observasi ke UMKM olahan keripik Anis Jaya

\section{PENUTUP}

\section{Simpulan}

Kegiatan pelatihan, workshop, dan obsevasi yang dilaksanakan dalam Program Pengembangan Minat Kewirausahaan dapat disimpulkan bahwa tenant memiliki motivasi dan minat yang tinggi dalam mengikuti semua kegiatan yang dilakukan. Kegiatan yang telah dilakukan juga dapat menumbuhkan minat berwirausaha bagi para tenant. Hal ini terbukti setelah kegiatan dilaksanakan para tenant termotivasi dan berminat untuk berwirausaha, walaupun ada beberapa tenant yang masih ragu-ragu dalam memulai usaha.

\section{Saran}

Saran-saran yang dapat direkomendasikan hasil pengabdian masyarakat ini adalah masih perlu diupayakan agar seluruh tenant mempunyai minat yang tinggi dalam berwirausaha, karena dengan minat yang tinggi akan dapat memengaruhi terwujudnya wirausahawan-wirausahawan baru. Tim pelaksana program pengembangan minat kewirausahaan Universitas Kanjuruhan Malang disarankan untuk memberikan pendampingan lebih lanjut kepada tenant khususnya tenant masih memiliki keraguan dalam membuka usaha baru.

\section{Ucapan Terima Kasih}

Ucapakan terima kasih disampaikan kepada DRPM Kemenristek Dikti yang telah mendanai kegiatan ini dalam bentuk Hibah Pengabdian. Terima kasih disampaikan juga kepada Rektor Universitas Kanjuruhan Malang yang telah mendukung kegiatan pengabdian ini secara nyata dengan memberikan dana pendamping. Ucapan terimakasih disampaikan juga Kepada Ketua LPPM, dan semua pihak yang telah mendukung serta memfasilitasi berlangsungnya kegiatan pengabdian ini.

\section{E. DAFTAR PUSTAKA}

Bahri S. dan Djamarah. 2008. Psikologi Belajar. Jakarta: Rineka Cipta.

Basrowi, 2011. Kewirausahaan Untuk Perguruan Tinggi. Ghalia Indonesia. Bogor.

Hendro, 2011. Dasar-Dasar Kewirausahaan. Erlangga. Jakarta.

Hisrich D. dan Robert. 2008. Entrepeneurship. Salemba 4. Jakarta.

Julianto, P.A. 2017. Perguruan Tinggi Harus Lahirkan Banyak Wirausaha Baru.https://ekonomi.kompas.com/r ead/2017/04/05/190830426/perguru an.tinggi.harus.lahirkan.banyak.wira usaha.baru diakses, 20 Agustus 2018.

Justin G. Longenecker. 2008. Kewirausahaan Dalam Manajemen Usaha Kecil. Salemba 4. Jakarta. 
Kotler, Philip. 2009. Manajemen

Pemasaran. Jakarta : Erlangga

Lambing and Kuehl, 2003,

Entrepreneurship Third

Edition, Prentice Hall, New

Jersey.

Peters and Hisrich, 1998,

Entrepreneurship

International,Edition, Irwin

McGraw-Hill.

Slameto. 2013. Belajar Dan Faktor-

Faktor Yang Mempengaruhinya.

Jakarta: Rineka Cipt 